\title{
MICROBIOLOGICAL PROFILE AND ANTIBIOTIC RESISTANCE PATTERN OF BACTERIAL UROPATHOGENS AMONG HOSPITALIZED PATIENTS
}

\author{
ANDREEA-LOREDANA GOLLI ${ }^{1}$, FLOAREA MIMI NIȚU ${ }^{1}$, MARIA BĂLĂȘOIU ${ }^{1}$, STEFAN \\ RASCU $^{2 *}$, MARINA ALINA LUNGU ${ }^{3}$, SORIN NICOLAE DINESCU ${ }^{1}$, LAVINIA CIOBANU- \\ MITRACHE $^{3}$, ADINA GLODEANU $^{1}$, MIRELA VĂCARU ${ }^{3}$, MIHAI OLTEANU $^{1}$ \\ ${ }^{1}$ University of Medicine and Pharmacy Craiova, Str. Petru Rareș, nr. 2, Craiova, Romania \\ ${ }^{2}$ University of Medicine and Pharmacy Carol Davila, Bucuresti \\ ${ }^{3}$ County Emergency Clinical Hospital Craiova, str. Tabaci nr.1, Craiova, Romania
}

*corresponding author: stefanrascu.sr@gmail.com

Manuscript received: August 2018

\begin{abstract}
Urinary tract infection (UTI) is the second most common type of infection and it may be a cause of considerable morbidity in case of recurrence. The aim of this retrospective study was to determine the distribution of pathogens involved in UTIs in hospitalized patients and their drug resistant pattern. It was analysed the distribution of the uropathogens from 427 urine samples collected from hospitalized patients from the urology clinic of County Emergency Clinical Hospital Craiova, between January to December 2017. Identification of the bacterial strains was performed on Chromagar (Oxoid) and the Vitek 2 Compact systems. The most common causative pathogens in UTIs were E. coli $(45.35 \%)$, followed by Klebsiella spp., Enterococcus spp., Enterobacter spp. (8.18\%). The strains of Enterobacteriaceae presented a high resistance to second and third generation cephalosporin, fluoroquinolones, and amoxicillin-clavulanic-acid. Surveillance of antibiotic prescription and monitoring studies are required to reduce the risk of drug resistance in bacterial uropathogens.
\end{abstract}

\section{Rezumat}

Infecția tractului urinar (ITU) este al doilea cel mai frecvent tip de infecție și poate fi o cauză de morbiditate considerabilă în cazul recidivei. Scopul acestui studiu retrospectiv a fost de a determina distribuția agenților patogeni implicați în ITU la pacienții spitalizați și profilul rezistenței lor la antibiotice. A fost analizată distribuția bacteriilor uropatogene izolate din 427 eșantioane de urină recoltate de la pacienții spitalizați în clinica de Urologie a Spitalului Clinic Județean de Urgență Craiova, în perioada ianuarie-decembrie 2017. Identificarea tulpinilor bacteriene s-a făcut pe mediul chromagar (Oxoid) şi pe sistemul Vitek 2 Compact. Cei mai frecvenți agenți patogeni cauzali ai ITU au fost E. coli (45,35\%), urmată de Klebsiella spp., Enterococcus spp., Enterobacter spp. (8,18\%). Tulpinile de Enterobacteriaceae au prezentat o rezistență ridicată la cefalosporine de a doua și a treia generație, fluoroquinolone și amoxicilină-acid clavulanic. Supravegherea studiilor privind prescrierea antibioticelor și studiile de monitorizare sunt necesare pentru a reduce riscul de rezistență la medicamente al bacteriilor uropatogene.

Keywords: urinary tract infections, strains distribution, antibiotic resistance

\section{Introduction}

Urinary tract infection (UTI) is the second most common type of infection and it may be a cause of considerable morbidity in case of recurrence. UTIs are the most common nosocomial infections in both acute-care hospitals and long-term-care facilities [11]. Over $95 \%$ of UTIs are caused by Enterobacteriaceae from which the most important is $E$. coli, responsible for $90 \%$ of the UTI in the non-hospitalized and 50\% hospitalized patients [8]. Other bacterial strains causing UTIs include Klebsiella, Proteus, Pseudomonas, Enterococcus, Enterobacter spp. etc. Organisms such as Serratia and Pseudomonas assume increasing importance in recurrent infections and infections associated with urologic obstructions. They also play a major role in nosocomial and catheter associated infections [1]. Among the risk factors for UTI are also gender, immune deficiencies, diabetes, chronic digestive disorders, associated genital disorders, prostatic or neurological disorders, obstructions in the urinary tract [8]. The emergence and widespread of antimicrobial resistance (AMR) is now considered a global public health threat [20]. Recurrent UTI are associated with bladder cancer [28] and might interfere the imunohistological differential diagnosis [22]. Starting from this reality, we analyzed the distribution and resistance patterns of the uropathogens to different drugs commonly used to treat urinary infections in hospitalized patients.

\section{Materials and Methods}

The study included the determination of pathogens involved in UTIs in patients admitted to the urology clinic of County Emergency Clinical Hospital Craiova, Romania, a county hospital with 1,518 
FARMACIA, 2019, Vol. 67, 1

beds, which provides healthcare to patients from Dolj county and Oltenia region. Data were collected from January 2017 to December 2017 from the clinical pathology databases of the hospital, including reports of technical procedures conducted and urine culture tests performed in the laboratory.

We analysed the resistance patterns for the action of the appropriate antibiotics for the isolated strains of urine specimens in the hospital's laboratory. Identification of the bacterial strains in the selected samples for this study was performed on Chromagar (Oxoid) and the Vitek 2 Compact system. A specimen was considered positive for UTI with a number of yielded colonies $\geq 10^{5}$ $\mathrm{CFU} / \mathrm{mL}$.

Antibiotic testing was carried out using the Vitek 2 Compact system and the diffusion method. Antibiotics agents employed for susceptibility testing were ampicillin-clavulanic acid $(20 / 10 \mu \mathrm{g})$, cefazolin $(30 \mu \mathrm{g})$, cefuroxime $(30 \mu \mathrm{g})$, ceftriaxone $(30 \mu \mathrm{g})$, ceftazidime $(30 \mu \mathrm{g})$, cefepime $(30 \mu \mathrm{g})$, ciprofloxacin $(5 \mu \mathrm{g})$, ofloxacin $(5 \mu \mathrm{g})$, vancomicyn $(30 \mu \mathrm{g})$, teicoplanin $(30 \mu \mathrm{g})$, piperacillin-tazobactam $(30 \mu \mathrm{g})$, imipenem $(10 \mu \mathrm{g})$, linezolid $(30 \mu \mathrm{g})$, tetracycline $(30 \mu \mathrm{g})$, penicillin $(10 \mu \mathrm{g})$, erytromycin $(15 \mu \mathrm{g})$, clindamycin $(2 \mu \mathrm{g})$, clarithromycin $(15 \mu \mathrm{g})$, doxycycline $(30 \mu \mathrm{g})$, oxacillin $(1 \mu \mathrm{g})$ and moxifloxacin
$(5 \mu \mathrm{g})$. Interpretation was done according to Clinical Laboratory Standard Institute (CLSI) guidelines [23]. Chi-square test was performed to evaluate antibiotic resistance patterns of bacteria. Differences were considered significant when $\mathrm{p} \leq$ 0.05 .

\section{Results and Discussion}

Between January and December 2017, there were analysed 427 samples from patients with urological diseases. The mean age of patients was $66 \pm 9.89$ years, 191 women $(44.73 \%)$ and 236 men $(55.26 \%)$ (Table I). Distribution of subjects by age group reflects the largest proportion of elderly patients ( $\geq 65$ years $-47.54 \%$ ), followed by the average age population (35-64 years- $33.72 \%$ ), young people (15-34 years $-10.3 \%)$ and children (0-14 ani$8.43 \%$ ). Elderly patients ( $\geq 65$ years) accounted for almost half (47.54\%) of total number of UTI cases, followed by age group 35-64 years $(33.72 \%)$ and $15-34$ years $(10.3 \%) .8 .43 \%$ from UTI cases were pediatric patients ( 0 -14 years).

A total of 452 bacterial isolates were recovered, of which $384(84.95 \%)$ of the isolates were Gram negative and 68 isolates $(15,04 \%)$ were Gram positive bacteria.

Table I

Distribution of study subjects regarding gender and age

\begin{tabular}{|c|c|c|c|c|}
\hline & & Age group & No & $\%$ \\
\hline \multirow{10}{*}{ Gender } & \multirow{5}{*}{ Female } & $\leq 14$ years & 17 & 8.90 \\
\hline & & $15-34$ years & 29 & 15.18 \\
\hline & & $35-64$ years & 66 & 35.55 \\
\hline & & $\geq 65$ years & 79 & 41.36 \\
\hline & & Total & 191 & 100 \\
\hline & \multirow{5}{*}{ Male } & $\leq 14$ years & 19 & 8.05 \\
\hline & & $15-34$ years & 15 & 6.35 \\
\hline & & 35-64 years & 78 & 33.05 \\
\hline & & $\geq 65$ years & 124 & 52.54 \\
\hline & & Total & 236 & 100 \\
\hline \multirow{5}{*}{\multicolumn{2}{|c|}{ Total subjects }} & $\leq 14$ years & 36 & 8.43 \\
\hline & & $15-34$ years & 44 & 10.3 \\
\hline & & $35-64$ years & 144 & 33.72 \\
\hline & & $\geq 65$ years & 203 & 47.54 \\
\hline & & Total & 427 & 100 \\
\hline
\end{tabular}

The most frequent isolate of the Gram negative uropathogens was $E$. coli $(45.35 \%)$, followed by Klebsiella spp. (20.79\%), Enterococcus spp. (9.73\%), Enterobacter spp. (8.18\%), Proteus spp.
(5.30\%), Pseudomonas spp. (3.09\%), Citrobacter spp $(1.32 \%)$, Glucose-nonfermenting Gramnegative bacilli (NFB) $(0.88 \%)$.

Table II

Microorganisms isolated from urine samples from hospitalized patients in Urology clinic of the County Emergency Clinical Hospital Craiova, Romania, between January-December 2017

\begin{tabular}{|l|c|c|c|c|c|c|}
\hline \multirow{2}{*}{ Microorganism } & \multicolumn{2}{|c|}{ Females } & \multicolumn{2}{c|}{ Males } & \multicolumn{2}{c|}{ Total } \\
\cline { 2 - 8 } & $\mathrm{n}$ & $\%$ & $\mathrm{n}$ & $\%$ & $\mathrm{~N}$ & $\%$ \\
\hline Escherichia coli & 94 & 47.23 & 111 & 43.87 & 205 & 45.35 \\
\hline Proteus mirabilis & 11 & 5.52 & 13 & 5.13 & 24 & 5.30 \\
\hline Klebsiella spp & 42 & 21.10 & 52 & 20.55 & 94 & 20.79 \\
\hline Citrobacter spp & 3 & 1.50 & 3 & 1.18 & 6 & 1.32 \\
\hline Enterobacter spp & 12 & 6.03 & 25 & 9.88 & 37 & 8.18 \\
\hline Pseudomonas aeruginosa & 4 & 28.57 & 10 & 71.42 & 14 & 3.09 \\
\hline
\end{tabular}


FARMACIA, 2019, Vol. 67, 1

\begin{tabular}{|l|c|c|c|c|c|c|}
\hline \multirow{2}{*}{ Microorganism } & \multicolumn{2}{|c|}{ Females } & \multicolumn{2}{c|}{ Males } & \multicolumn{2}{c|}{ Total } \\
\cline { 2 - 8 } & $\mathrm{n}$ & $\%$ & $\mathrm{n}$ & $\%$ & $\mathrm{~N}$ & $\%$ \\
\hline MRSA & 10 & 5.02 & 10 & 3.95 & 20 & 4.42 \\
\hline Enterococcus spp & 22 & 11.05 & 22 & 8.69 & 44 & 9.73 \\
\hline CoNS & 0 & 0 & 3 & 1.18 & 3 & 0.66 \\
\hline NFB & 1 & 0.50 & 3 & 1.18 & 4 & 0.88 \\
\hline Gram positive bacilli & 0 & 0 & 1 & 0.39 & 1 & 0.22 \\
\hline Total & 199 & 100 & 253 & 100 & 452 & 100 \\
\hline
\end{tabular}

MRSA - Methicillin-Resistant Staphylococcus Aureus; NFB-Glucose-non-fermenting Gram-negative bacilli; CoNS -Coagulase-negative staphylococci

Other investigators have also reported the same first two uropathogens involved in UTIs. The frequency of Escherichia coli in urine samples, which is the most frequent cause of bloodstream and urinary tract infections in Europe, varies in different studies [2]. According to our study, E. coli and Klebsiella spp. detained $66 \%$ of the total isolates, representing first and second Gram negative strains, while Enterococcus spp. and Methicillin-Resistant Staphylococcus aureus (MRSA) were the first and second predominant Gram positive bacteria, accounting for $14.15 \%$ from all isolates.

Differences in isolation rates of E. coli, Klebsiella spp., Proteus spp., Enterobacter spp., Pseudomonas spp. were observed between males and females. Referring to the total number of samples collected by gender, isolation rates indicates a higher value for female patients for E.coli (47.23\% compared to $43.87 \%)$, Klebsiella spp. $(21.10 \%$ compared to $20.55 \%)$, Enterococcus spp. (11.05\% compared to $8.69 \%)$, MRSA $(5.02 \%$ compared to $3.95 \%)$. Instead, other microorganisms were more frequently responsible for UTIs in males than in females, such as Enterobacter spp. $\quad(9.88 \%$ compared to $6.03 \%$ ) and Pseudomonas aeruginosa, with an almost double value $(3.95 \%$ compared to $2.01 \%$ ).

Most strains of E. coli were isolated in subjects over 65 years of age $(42.55 \%$ in women and $53.47 \%$ in men, the difference being not statistically significant), followed by the age group $35-64$ years $(34.04 \%$ in women and $36.43 \%$ in men). The percentage was lower than that reported in other study $[9,10] .15 .95 \%$ of the E. coli strains were isolated from urine samples collected from female patients aged 15-34 years and $6.30 \%$ from male patients of the same age, the difference being statistically significant $(\chi 2=4.94, \mathrm{p}=0.02)$.

$45.23 \%$ of the Klebsiella spp. strains were isolated in women over 65 years and $55.76 \%$ in males over 65 years of age, with only 3 cases being recorded in children $\leq 14$ years.

The third most involved uropathogen according to our study was Enterococcus spp., representing almost $10 \%$. More than half of the strains of Enterococcus spp. were isolated in men aged 35-64 years, while in females, the largest percentage $(45.45 \%)$ was found in elderly people ( $\geq 65$ years) . This frequency is close to that evidenced by the results of another study conducted in Romania on a group of 85 elderly outpatients [10]. Vallejo-Torres
L et al. revealed the presence of Enterococcus spp. in a percentage of $5 \%$ in a study evaluating the costs of hospitalised patients due to complicated urinary tract infections in 20 hospitals from 8 countries including Romania, with high prevalence of multidrug-resistant Gram-negative bacteria. [27] In other studies the third place after E. coli and Klebsiella spp. was occupied by coagulase-negative staphylococci (CoNS) [25], Proteus spp. [14] or NFB [5]. In other studies, the most common pathogens other than E.coli, involved in UTIs, were, Staphylococcus aureus or Staphylococcus saprophyticus [12].

Antimicrobial resistance (AMR) is a serious threat to public health and patient safety in Europe, leading to increasing healthcare costs, patient treatment failure, and deaths. [2] Several classes of bacteria have already exhibited multidrug resistance to antibiotics, such as Klebsiella pneumoniae and $E$. coli strains producing extended-spectrum betalactamase (ESBL), which hydrolyses the betalactam ring of penicillin, cephalosporins, and other related antibiotics, contributing to treatment failure $[7,26]$.

While antibiotics are considered the most effective method of treatment for bacterial infections, their empirical, indiscriminate, prolonged, or incorrect usage contributes significantly to the emergence of new infections by leading to the selection of resistant strains [15, 17]. For instance, $20 \%$ of relapses and $3.7 \%$ of new cases of tuberculosis are caused by rifampicin- and isoniazid-resistant strains of Mycobacterium tuberculosis [29]. The migration phenomenon contributes to the increased multidrug resistance stains [4].

In the case of urinary (TB), the kidney is the most important site of extra-pulmonary TB [8]. Extrapulmonary tuberculosis includes all TB affects except pleura, lungs, intra-thoracic lymph nodes and larynx, and originates from the hematogenous metastatic affects developed during the prime TB infection period [21].

The evolution of this type of tuberculosis may be early, before the primary infection has healed or long after the primary infection by reactivation of healed lesions. [18] Cutaneous tuberculosis represents a small percent of total extrapulmonary TB forms, caused mainly by Mycobacterium tuberculosis. The form of the disease depends on the virulence of the strain, the immune status of the host, the portal of entry, the internal spread pattern, and the adequacy 
of the initial treatment [19] and is extremely important in countries with both high and low TB incidence [3, 4].

Fungal UTIs occur in urinary catheterized patients, people receiving broad-spectrum antibiotics or immunosuppressed patients. [8]

The present study revealed that uropathogens isolated from urine samples of patients with UTIs presented high levels of single and multiple antimicrobial resistance.
The antibiotic resistance rates of the isolates are summarized in figure 1 . Over $70 \%$ from Enterobacteriaceae were resistant to ampicillinclavulanic acid, cefazolin, cefuroxime, while half of them were susceptible to ceftriaxone, $63 \%$ to cefepime, $60.18 \%$ to piperacillin-tazobactam and almost all to imipenem $(93.87 \%)$. Regarding fluoroquinolones, $69.12 \%$ of Enterobacteriaceae were resistant to ciprofloxacin.

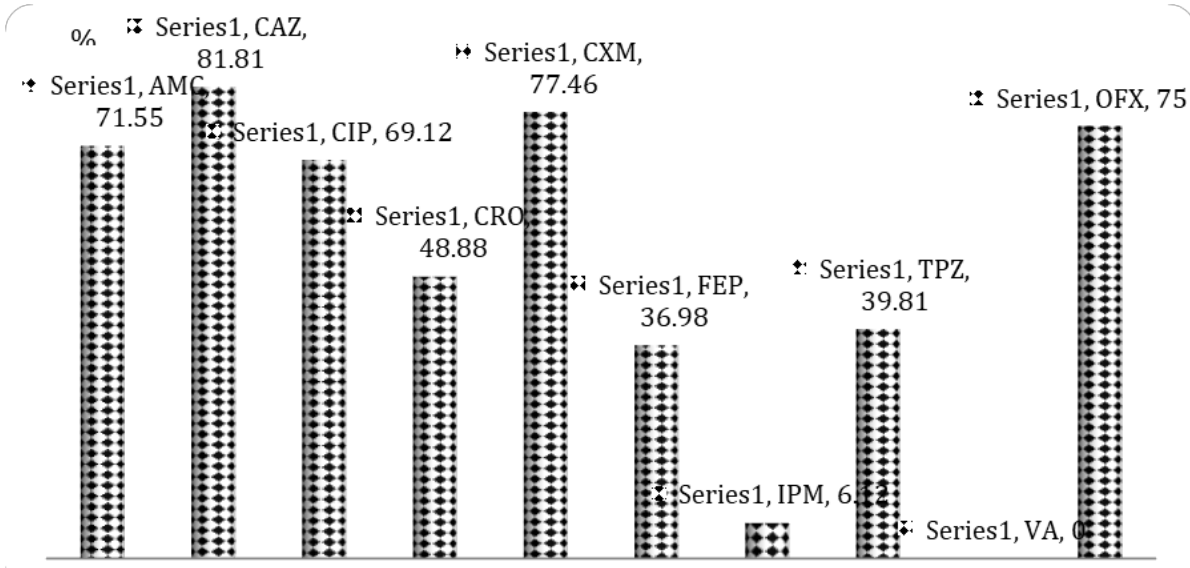

Figure 1

Resistance pattern of Enterobacteriaceae to the tested antibiotics. AMC- ampicillin-clavulanic acid; CAZ- ceftazidime ; CIP - ciprofloxacin; CRO - ceftriaxone; CXM- cefuroxime; FEP- cefepime; IPM - imipenem; TPZ - piperacillin-tazobactam; VA- vancomicyn (only Enterobacter spp.); OFX - ofloxacin (only Enterobacter spp.).

Around $65 \%$ of E. coli isolates were resistant to ampicillin-clavulanic acid and ciprofloxacin and almost $75 \%$ to cefuroxime. The strains tested were almost entirely susceptible to imipenem, $64.5 \%$ to ceftriaxone and $72.48 \%$ to cefepime. The results are consistent with analyses from the European Centre for Disease Prevention and Control [2].

Another study reflected more than $20 \%$ prevalence of resistance among $E$. coli and all isolates combined for ampicillin, cephalothin, and sulfamethoxazole [12], while other researchers have found that $100 \%$ of $E$. coli and $K$. pneumonia isolates were resistant to amoxicillin and ampicillin [6], or a high susceptibility to ciprofloxacin [16].

According to the Annual report of the European Antimicrobial Resistance Surveillance Network, the highest resistance percentages in $E$. coli were generally reported from southern and south-eastern Europe [2].

Combined resistance to multiple antimicrobial groups was observed for Klebsiella spp., consistent with European Centre for Disease Prevention and control (ECDC). Almost all strains of Klebsiella spp. $(92.95 \%)$ were resistant to ampicillinclavulanic acid, about $85 \%$ at cefuroxime, $73.11 \%$ at ciprofloxacin, and nearly $70 \%$ at ceftazidime. Around $93 \%$ of the tested strains were sensitive to imipenem and $61 \%$ to cefepime. Although ECDC analysis places Romania between the three countries with the highest carbapenem resistance
[2], in the present study the susceptibility rate for the tested Klebsiella spp. strains was $92.85 \%$.

The majority of infections caused by $K$. pneumoniae are healthcare-associated and the most common resistance phenotype has combined resistance to three key antimicrobial groups: fluoroquinolones, third-generation cephalosporins and aminoglycosides [2].

Between $1-2.5 \%$ of hospitalized patients have nosocomial urinary infections, the incidence of which is variable according to the characteristics of the service in which the patients are hospitalized and of the hospital. [13] Results of various European national prevalence studies show that they account for $23-49 \%$ of all nosocomial infections [11].

UTIs associated with catheter use account for 30 $40 \%$ of all nosocomial infections and are the most common source of Gram-negative bacteraemia in hospitalized patients [24].

In our study, $88.23 \%$ of Enterobacter strains tested were susceptible to imipenem and all at vancomicyn, while over two-thirds were resistant to ceftazidime $(63.63 \%)$, ampicillin-clavulanic acid $(72.41 \%)$, ciprofloxacin $(76.31 \%)$, ceftriaxone $(83.78 \%)$, cefepime $(69.66 \%)$. Over $80 \%$ of the tested strains showed resistance to ciprofloxacin and doxycycline, almost $94 \%$ to tetracycline. The two strains tested with oxacillin were resistant. The most effective antibiotic was linezolid (in over $95 \%$ 
of cases), followed by ciprofloxacin (86.36\%), vancomicyn, doxycycline, and teicoplanin (over $80 \%)$.

Resistance to ampicillin-clavulanic acid was observed in $90 \%$ from isolates of Proteus spp., while $79.16 \%$ were resistant to cefazolin, almost $71 \%$ to ciprofloxacin and $65.21 \%$ la cefuroxime. Only half of the Proteus strains were susceptible to ceftriaxone.

All tested strains of Pseudomonas aeruginosa (figure 2) were resistant to ampicillin-clavulanic acid, ceftriaxone, cefuroxime, cefazolin, $87.5 \%$ to ceftazidime, $78.5 \%$ to ciprofloxacin. Instead, all tested strains were susceptible to vancomicyn. 17 strains from the 20 identified, were resistant to clindamycin, clarithromycin and penicillin, while $75 \%$ (15) were resistant to erytromycin and tetracycline. $55 \%$ from the isolates were resistant to piperacillin-tazobactam, consistent to ECDC analysis [2].

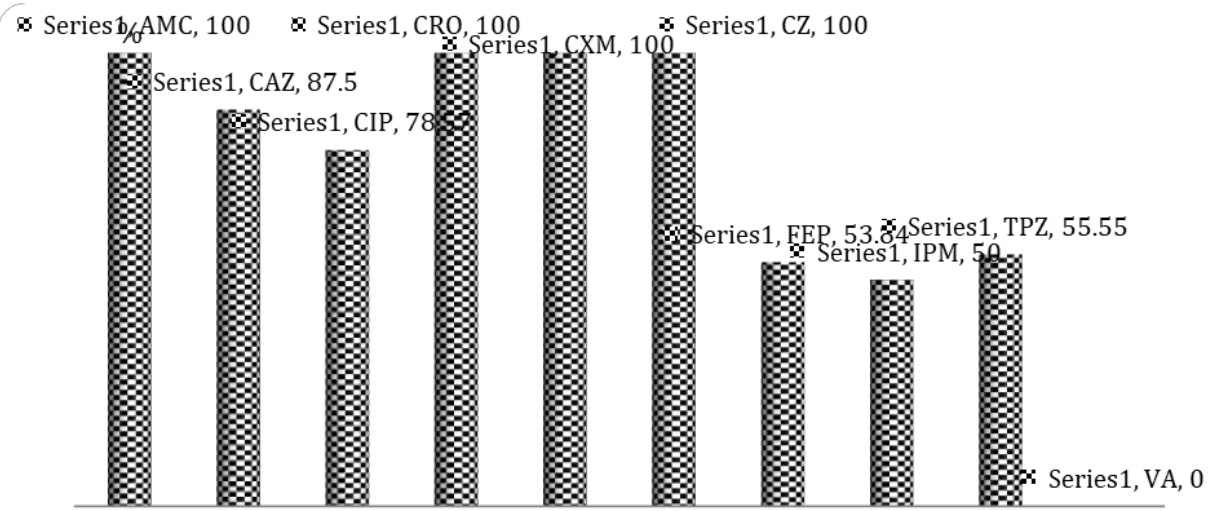

Figure 2

Resistance pattern of Pseudomonas aeruginosa to the tested antibiotics. AMC- ampicillin-clavulanic acid; CAZ- ceftazidime; CIP - ciprofloxacin; CRO - ceftriaxone; CXM- cefuroxime; CZ - cefazolin; FEP- cefepime; IPM - imipenem; TPZ piperacillin-tazobactam; VA- vancomicyn

The most active antibiotic against MRSA (figure 3) was linezolid, with almost all strains (19) being sensitive. A very high level of resistance was highlighted in the case of clindamycin and clarithromycin $(85 \%)$, penicillin and erytromycin $(75 \%)$ and ciprofloxacin $(66.66 \%)$. MRSA has been the most important cause of antimicrobial-resistant healthcare-associated infections worldwide [2], with higher percentages in the southern and southeastern parts of Europe.

All tested strains of Citrobacter were resistant to ampicillin-clavulanic acid and two thirds of them at ceftazidime, cefuroxime and cefazolin. Half of them were sensitive to ceftriaxone and cefepime, and two thirds to imipenem and piperacillintazobactam.

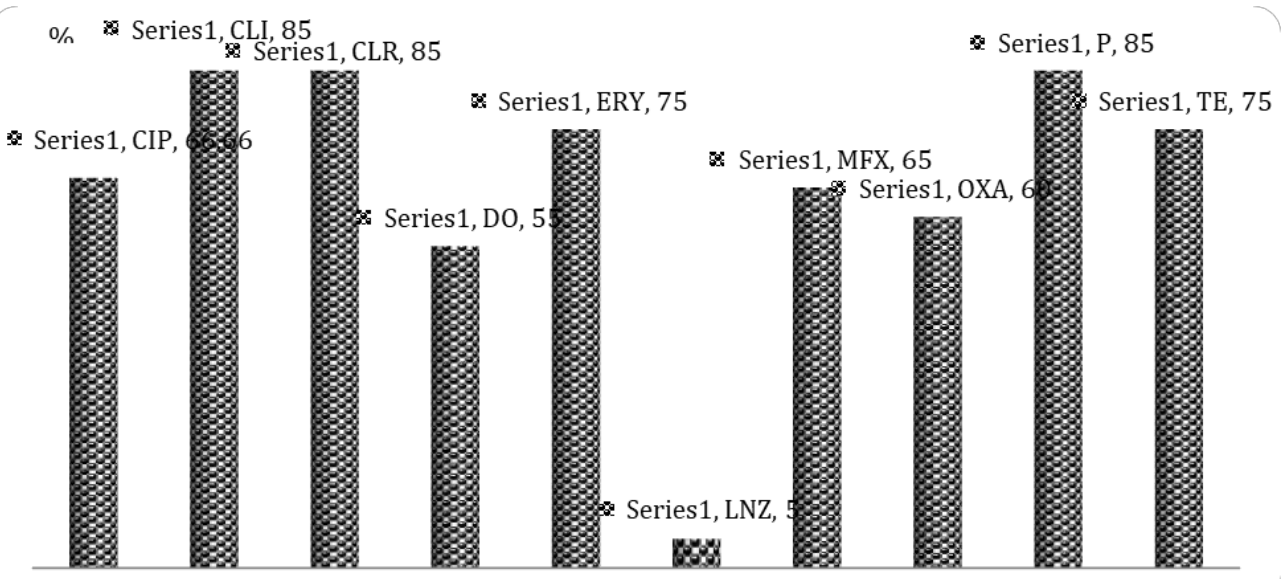

Figure 3

Resistance pattern of MRSA to the tested antibiotics. CIP - ciprofloxacin; CLI - clindamycin; CLR - clarithromycin; DO doxycycline; ERY - erytromycin; LNZ - linezolid; MFX - moxifloxacin; OXA - oxacillin; P - penicillin; TE - teicoplanin. 
The phenotypes of betalactamine resistance are presented in Table III.

Table III

Distribution of phenotypes resistant to betalactamines of the isolated bacterial strains.

\begin{tabular}{|l|c|c|c|c|c|c|}
\hline Bacteria strains isolated & Wild (\%) & ESBL (\%) & PHN (\%) & PLN (\%) & CHN (\%) & TRI (\%) \\
\hline Escherichia coli $(n=205)$ & - & 4.30 & 1.94 & 0.09 & 3.94 & 1.01 \\
\hline Klebsiella spp $(n=94)$ & 16.13 & 9.37 & - & - & 1.17 & - \\
\hline Enterobacter $\operatorname{spp}(n=37)$ & 15.20 & 9.25 & - & - & 1.5 & - \\
\hline Pseudomonas aeruginosa $(n=14)$ & - & 6.58 & - & - & 1.27 & - \\
\hline
\end{tabular}

ESBL: Extended-Spectrum Beta-Lactamase; PBN: Low Level Penicillinase; PHN: High Level Penicillinase; CHN: High Level Cephalosporinase; TRI: Resistant to inhibitors

Because the annual data collected by ECDC's European Antimicrobial Resistance Surveillance Network (EARS-Net) [2] consistently places Romania among the vulnerable countries, this study is the starting point of further research to highlight the evolution in time of the germ resistance.

\section{Conclusions}

The study revealed the presence of a large number of $E$. coli resistant to aminopenicillins and betalactamase inhibitors, of Klebsiella, Enterobacter, Proteus, Pseudomonas aeruginosa and MRSA pathogens that can induce nosocomial urinary infections.

Surveillance of antibiotic prescription and monitoring studies are required to reduce the risk of resistance, together with collaborative actions by the epidemiologist, microbiologist and clinician to adopt individual therapeutic measures, defining an antibiotic-prevention protocol or therapy, discriminating between the community and hospital strains.

\section{References}

1. Anuli S, Mboto CI, Agbo B, A review on the prevalence and predisposing factors responsible for urinary tract infection among adults. Eur $J$ Experim Biol., 2016; 6(4): 7-11.

2. www.ecdc. europa.eu.

3. Arghir OA, Dantes E, Otelea M, Rascu A, Borgazi E, Cambrea SC. Eight-year survey of tuberculosis inhospital mortality in the South Eastern part of Romania. Rom J Leg Med., 2018; 26(2): 183-187.

4. Arghir OC, Pereira PMA, Rascu A, Dantes E, Borgazi E, Iliescu DM, Oțelea MR, Cambrea SC. The impact of migrant tuberculosis on the chimioresistance pattern of antituberculosis drugs in a low burden tb european country. Farmacia, 2018; 66(3): 537-540.

5. Benachinmardi K, Padmavathy M, Malini J, Navaneeth BV, Microbiological profile and antibiogram of uropathogens in pediatric age group. Int J Health Allied Sci., 2015; 4: 61-64.

6. Beyene G, Tsegaye W, Bacterial uropathogens in urinary tract infection and antibiotic susceptibility pattern in Jimma University Specialized Hospital, Southwest Ethiopia. Ethiop J Health Sci., 2011; 21(2): 141-146.

7. Cherkaoui A, Emonet S, Renzi G, Riat A, Greub G, Schrenzel J, ESBL and carbapenemases in
Enterobacteriaceae. Rev Med Suisse., 2014; 10: 2142-2148

8. Ciocâlteu A, Clinical Nefrology, Infomedica Publishing House, Bucharest, 1998, 154 (availible in Romanian).

9. De Vecchi E, Sitia S, Romano CL, Ricci C, Mattina $\mathrm{R}$, Drago L, Aetiology and antibiotic resistance patterns of urinary tract infections in the elderly: a 6month study. J Med Microbiol., 2013; 62(Pt6): 859863.

10. Delcaru C, Podgoreanu P, Alexandru I, Popescu N, Măruțescu L, Bleotu C, Mogoșanu GD, Chifiriuc MC, Gluck M, Lazar V, Antibiotic Resistance and Virulence Phenotypes of Recent Bacterial Strains Isolated from Urinary Tract Infections in Elderly Patients with Prostatic Disease. Pathogens., 2017; 6(2): 22.

11. Gastmeier P, Nosocomial urinary tract infections: many unresolved questions. Clin Microbiol Infect., 2001; 7(10): 521-522.

12. Gupta K, Scholes D, Stamm WE, I ncreasing prevalence of antimicrobial resistance among uropathogens causing acute uncomplicated cystitis in women, JAMA, 1999; 281(8): 736-738.

13. Ivan A, Epidemiology treaty on contagious Diseases, 2002, 744 (available in Romanian).

14. Kibret M, Abera B, Prevalence and antibiogram of bacterial isolates from urinary tract infections at Dessie Health Research Laboratory, Ethiopia. Asian Pac J Trop Biomed., 2014; 4(2): 164-168.

15. Laxminarayan R, Duse A, Wattal C, Zaidi AK, Wertheim HF, Sumpradit N, Vlieghe E, Hara GL, Gould IM, Goossens H Greko C, So AD, Bigdeli M, Tomson G, Woodhouse W, Ombaka E, Peralta AQ, Qamar FN, Mir F, Kariuki S, Bhutta ZA, Coates A, Bergstrom R, Wright GD, Brown ED, Cars O, Antibiotic resistance - The need for global solutions. Lancet Infect Dis., 2013; 13(12): 1057-1098.

16. Lee SJ, Leeb SD, Chob IR, Simb BS, Leeb JG, Kimb CS, Kimb ME, Choab YH, Wooc YN, Antimicrobial susceptibility of uropathogens causing acute uncomplicated cystitis in female outpatients in South Korea: a multicentre study in 2002. Int $J$ Antimicrob Agents, 2004; 27(Suppl 1): S61-S64.

17. Llor C, Bjerrum L, Antimicrobial resistance: Risk associated with antibiotic overuse and initiatives to reduce the problem. Ther Adv Drug Saf., 2014; 5(6): 229-241.

18. Nemeş RM, Ianoşi ES, CS, Postolache P, Streba CT, Olteanu M, Golli AL, Madalina Olteanu, Niţu MF, Tuberculosis of the oral cavity. Rom J Morphol Embryol., 2015; 56(2): 543-547.

19. Nitu M, Olteanu M, Călărasu C, Olteanu M, Vasiliu R, Streba C, Postolache P, Golli AL, Pop C, Nemeş 
RM, A comparison between cutaneous tuberculosis and leprosy. Arch Balk Med Union, 2015; 51(1): 105-111.

20. Núnez M, Navarro MD, Palomo V, Rajendran NB, del Toro MD, Voss A, Sharland M, Sifakis F, Tacconelli E, Rodríguez-Bano J, The methodology of surveillance for antimicrobial resistance and healthcare-associated infections in Europe (SUSPIRE): a systematic review of publicly available information. Clin Microbiol Infect., 2018; 24(2): 105-109.

21. Olteanu M, Nitu M, Golli A, Case report Tuberculosis mesenteric adenopathy and polyserositis. Rom J Morphol Embryol., 2012; 53(3 Suppl): 835-840.

22. Oțelea MR, Jinga V, Rașcu ASC, Pleșea IE, Petrescu A, Mitrache L, Olteanu M, Bondari D, Raşcu A, Occupational exposure to urinary bladder carcinogens - risk factors, molecular mechanisms and biomarkers. Rom J Morphol Embryol., 2018; 59(4): in press.

23. Patel JB, Weinstein MP, Eliopoulos GM, Jenkins SG, Lewis JS, Limbago B, Mathers AJ, Mazzulli T, Patel R, Richter SS, Satlin M, Swenson JM, Traczewski MM, Turnidge JD, Zimmer BL, CLSI. Performance Standards for Antimicrobial Susceptibility Testing; 27th Edition, Clinical and Laboratory Standards Institute, ISBN 978-1-68440033-1.

24. Soto SM, Importance of biofilms in urinary tract infections: New therapeutic approaches. Adv Biol. 2014; 2014: 1-14.
25. Tiruneh M, Yifru S, Gizachew M, Molla K, Belyhun Y, Moges F, Endris M, Changing trends in prevalence and antibiotics resistance of uropathogens in patients attending the Gondar University Hospital, Northwest Ethiopia. Int J Bacteriol., 2014; 2014: 17.

26. Trang NHT, Nga TVT, Campbell JL, Hiep NT, Farrar J, Baker S, Duy PT, The characterization of ESBL genes in Escherichia coli and Klebsiella pneumoniae causing nosocomial infections in Vietnam. J Infect Dev Ctries., 2013; 15(7): 922-928.

27. Vallejo-Torres L, Pujol M, Shaw E, Wiegand I, Vigo JM, Stoddart M, Grier S, Gibbs Vank JC, Cuperus N, van den Heuvel L, Eliakim-Raz N, Carratala J, Vuong C, MacGowan A, Babich T, Leibovici L, Addy I, Morris S, Cost of hospitalised patients due to complicated urinary tract infections: a retrospective observational study in countries with high prevalence of multidrug-resistant Gramnegative bacteria: the COMBACTE-MAGNET, RESCUING study. BMJ Open, 2018; 8: 1-9.

28. Vermeulen SH, Hanum N, Grotenhuis AJ, CastañoVinyals $G$, van der Heijden AG, Aben KK, Mysorekar IU, Kiemeney LA, Recurrent urinary tract infection and risk of bladder cancer in the Nijmegen bladder cancer study. Br J Cancer., 2014; 112(3): 594-600.

29. World Health Organization, Tuberculosis. Saudi Med J., 2013; 34(11): 1205-1207. 